моделюв ння / . . евченко, . . технічний эмурн $\Omega$ « існик ернівецького держ вного технологічного університету». - 2006. - №2. - . 63-71.

$$
\text { 11. евченко . . оняття достовірності }
$$
м тем тичних моделей вип дкових процесів / . . евченко // існик ціон льного університету
" ввівськ політехнік» “нформ иійні системи m мережкі“. - 2009. - №6(21) . - . 239-250.

дійщл до ред киії 20.10.2010 p.

ецензент: доктор технічних н ук, ст рший н уковий співробітник . . убков, к демія сухопутних військ імені гетьм н етр г йд чного, ьвів.

. . евченко, . . гинский

ст тье приведены основные положения метод пересчет эксперимент льных д нных, полученных во время полигонных испыт ний оптико-электронных средств р зведки для их нормиров ния. спользов ние предл г емого метод позволяет обеспечить ст тистическую обр ботку эксперимент льных зн чений д льности обн ружения оптико-электронных средств н блюдения , которые получены в р зличных условиях и по происхождению не является однородными.

лючевые слов : объекты р зведки, р зведыв тельный орг н, оптико-электронные средств н блюдения, боевые р зведыв тельные м иины, д льность обн ружения.

\title{
ADVANCED METHOD OF TREATMENT EXPERIMENTOF DATA OF CHECK OF RANGE OF DETECTION OPTICAL-ELEKTRONIC MEANS OF INVESTIGATION COMBAT RECONNAISSANCE VEHICLE
}

\author{
A.O.Levchenko, V.A.Baginskiy
}

In article substantive provisions of a method of recalculation of the experimental data received during time Range of tests for opticalo-elektronical means of investigation for their rationing are resulted. Use of a method which is offered allows to provide statistical treatment of experimental values of range of detection opticalo-elektronical surveillance facilities combat reconnaissance vehicle which are received in various conditions and by origin are not homogeneous.

Keywords: Objects of investigation, prospecting body, optical-elektronical surveillance surveillance facilities, combat reconnaissance vehicles, range of detection.

\author{
$621.396+629.7$ \\ . . врінчук \\ ціон льний університет оборони кр їни, иїв
}

ст тті проведено н ліз існуючих підходів до оцінки жсивучості скл дних систем військового призн чення $m$ з пропонов но методику визн чення $n$ р метрів оптим льного упр вління випромінюв нням р діон віг ційної інформ ції, як б зуеться н основі оцінки жкивучості псевдосупутникової р діон віг ційної системи в ициклі тї функціонув ння.

лючові слов : псевдосупутников р діон віг ційн систем, жсивучість, $n$ р метри упр вління випромінюв нням р діон віг ційної інформ ції.

ост новк проблеми. Д ний ч с вирішення б г тьох н родногоспод рських, оборонних і н укових 3 вд нь неможливе без якісного т безперервного н віг ційного з безпечення. собливої кту льності це н був є у військовій сфері. ому створенню т 3 стосув нню $\mathrm{p}$ діон віг ційних систем приділяється зн чн ув Г у всіх розвинених кр їн х світу. н ліз публік цій. явні в кр їні г лузеві з соби н віг ції і єдиного ч су не дозволяють з безпечити н необхідному рівні вирішення з вд нь н ціон льної безпеки т оборони, т кож не можуть з безпечити потреби фунд мент льної і прикл дної н уки. я обст вин зумовлен відсутністю їх інтегр ції в з г льнодерж вну 
систему інформ ційного з безпечення процесів упр вління рухомими об'єкт ми, т кож їх мор льною і фізичною з ст рілістю, виробленням свого ресурсу т необхідністю ремонту і з міни, що, як н слідок, не з довольняє постійно зрост ючі вимоги спожив чів $[1,2,3]$. метою вирішення вищез зн ченої проблеми в кр їні розроблен т 3 тверджен ерж вн цільов н уково-технічн прогр м створення держ вної інтегров ної інформ ційної системи з безпечення упр вління рухомими об'єкт ми (зв'язок, н віг ція, спостереження) 3 терміном викон ння 2008 2011 роки, одним із з вд нь якої $€$ “створення системи н віг ції, що б зується н суч сних технологіях, для розвитку вітчизняних з собів н віг ції і впров дження їх у систему упр вління всім вид ми тр нспорту т користув ння цією системою орг н ми , , іноборони, , "[3].

хівцями ктивно обговорюються шляхи ре ліз ції н віг ційного з безпечення цивільних і військових спожив чів кр їни. ідповідно до їх пропозицій перспективне н віг ційне з безпечення, що з довольняє 3 пит м всіх спожив чів кр їни, доцільно б зув ти н використ нні глоб льних н віг ційних полів, створюв них середньоорбіт льними супутниковими р діон віг ційними систем ми ( ) NAVSTAR i $[1,3]$. досвідом лок льних війн т збройних конфліктів ост нніх десятиліть, при вирішенні 3 вд нь н віг ційного з безпечення військ в рто використовув ти с ме космічні н віг ційні системи, що доповнені н земним сегментом опорних ст нцій, які ре лізують диференційний режим визн чень 3 метою їхього якісного доповнення $[4,5]$. зом 3 тим при т кому підході якість н віг ційного з безпечення більшості спожив чів ст виться в певну з лежність від політики військових відомств i осії, які розвернули і контролюють

NAVSTAR i i визн ч ють політику їх використ ння. снує т кож проблем н дійності н віг ційного з безпечення, як поляг є в тому, що у $\mathrm{p}$ зі відмови н віг ційного космічного п р т ( $\quad$ ) інформ ція про це поступ є спожив ч м 3 великим з пізненням (до декількох годин).

ет ст тті. ровести н ліз існуючих підходів до оцінки живучості скл дних систем військового призн чення т 3 пропонув ти методику визн чення п р метрів оптим льного упр вління випромінюв нням р діон віг ційної інформ ції.

\section{Сновн ч стин}

пр ктиці одним 3 н йбільш перспективних н прямків вирішення 3 д чі н віг ції існуючими прийм ч ми супутникових сигн лів в умов $\mathrm{x}$ відсутності н віг ційного поля глоб льних $\epsilon$ використ ння лок льної псевдосупутникової p діон віг ційної системи ( ) $[2,6]$. севдосупутник - це перед в ч сигн лів, що подібні сигн л м н віг ційних космічних п р тів і можуть бути використ ні для н віг ційних вимірів як р зом 3 інформ цією , т к і втономно. кий перед в ч може бути вст новлений н поверхні землі (ст ціон рно чи н рухомих з соб х), бо у повітрі (н будь-якому літ льному п р ті).

н ліз ряду джерел інформ ції [2, 6 - 9] щодо способів побудови б г топозиційних свідчить про те, що їх топологічні структури синтезуються лише 3 критеріями м ксимуму площі зони покриття системи т м ксимуму точності місцевизн чення спожив чів. ри т кому способі побудови неможливе безперервне т стійке з безпечення p діон віг ційною інформ цією ( ) всіх 3 цік влених (в першу чергу, військових) спожив чів в умов $\mathrm{x}$ бойової обст новки, коли неминучим $\epsilon$ пошкодження чи знищення ряду р діон віг ційних точок ( ) вн слідок фізичного впливу противник .

рис. 1 н ведені протиріччя, які виник ють при синтезі , можливі шляхи підвищення їх живучості в умов х ктивного впливу противник .

ур хув нням цього кту льним є пит ння оцінки живучості лок льних бг топозиційних (псевдосупутникових) $\mathrm{T}$ н земних функціон льних доповнень глоб льних н віг ційних супутникових систем ( ) 3 метою визн чення п р метрів оптим льного упр вління просторово-ч совим випромінюв нням ними , що н д сть змогу ускл днити противнику процес виявлення елементів т їх знищення, підвищуючи т ким чином живучість системи $\mathrm{T}$ безперервність і стійкість з безпечення н віг ційною інформ цією військових спожив чів. ст тті проводиться н ліз існуючих підходів до оцінки живучості скл дних систем військового призн чення т обгрунтув ння вибору п р метрів оптим льного упр вління просторово-ч совим випромінюв нням в зі змінною структурою.

освід створення скл дних систем військового призн чення вк зує н те, що проблем з безпечення необхідного рівня їх живучості м $€$ першочергове зн чення. ід живучістю [10-12] розуміється зд тність системи до збереження своїх основних функцій при впливі ф кторів зовнішнього середовищ к т строфічного х р ктеру несприятливих впливів, що виходять 3 р мки проектних умов експлу т ції. ншими слов ми, живучість - це вл стивість об'єкт, як поляг є в його спроможності виконув ти 3 вд ння 3 призн ченням у процесі несприятливих впливів н весь об'єкт бо окремі його елементи, підтримуючи в допустимих меж х свої експлу т ційні пок зники. 


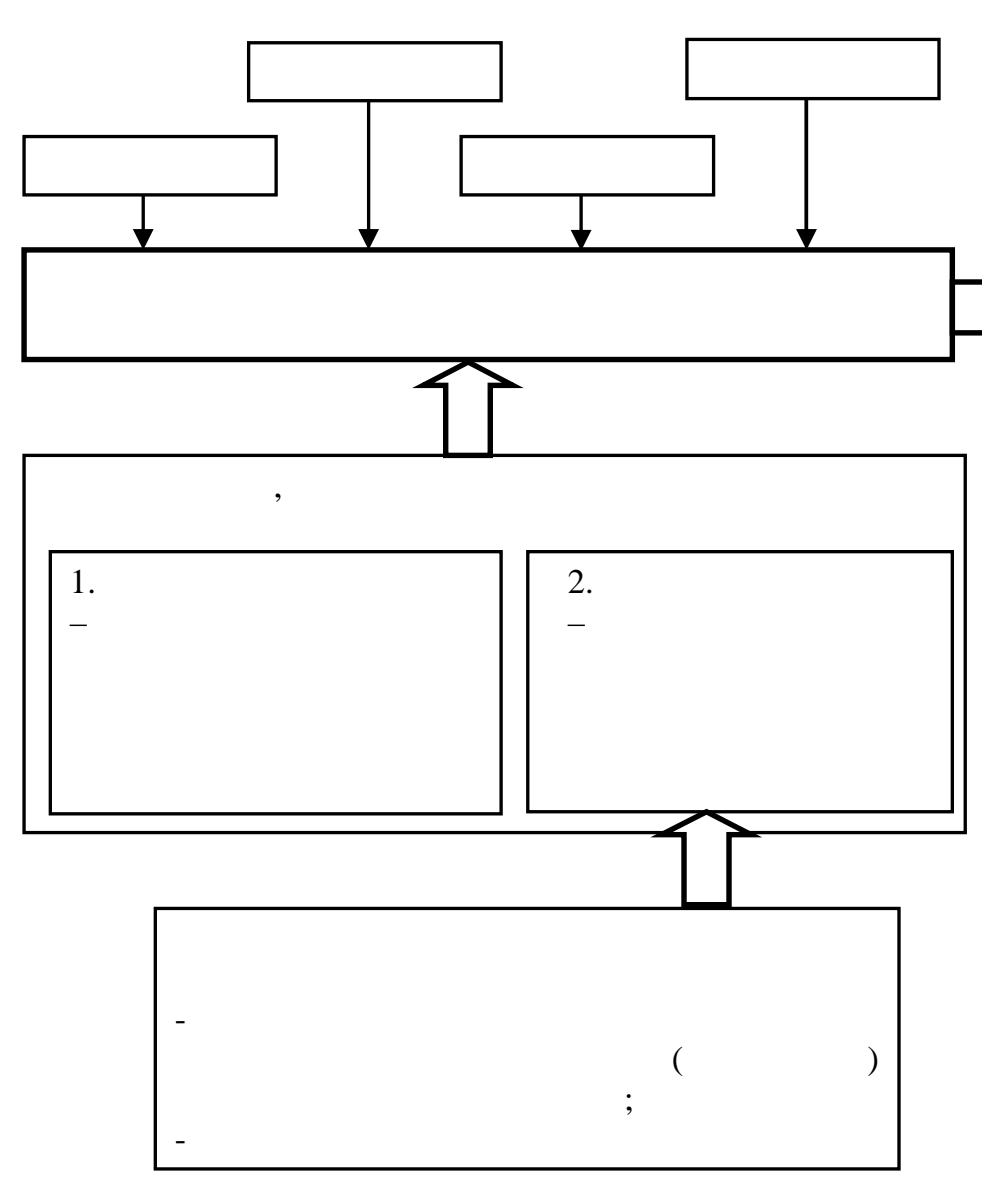

uc.1. ротиріччя, що виник ють при синтезі
- 3 max точності;

- 3 max площі робочої зони

не вр ховується можливість втр ти окремих елементів структури в результ ті впливу противник
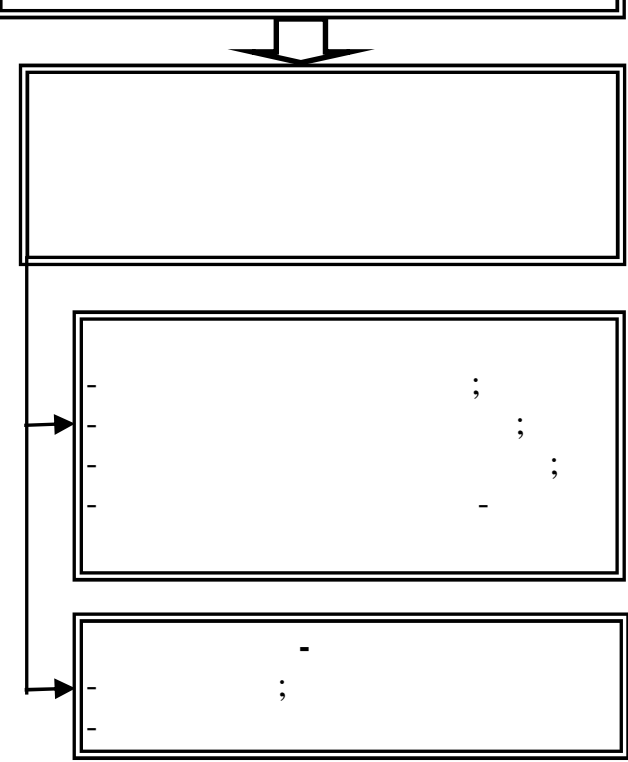

, т можливі шляхи їх вирішення иходячи з точки зору живучості $\mathrm{T}$

, iіï доцільно розгляд ти н об'єктовому, структурному т функціон льному рівнях [12 - 14].

ід об'єктовою живучістю

$O \quad P H C$

розуміється імовірність збереження елементів

після вогневого впливу противник [15]:

$$
\begin{aligned}
& =\left\lfloor\left(W_{1} \leq W_{1 \text { доn }}\right) \cup\left(W_{2} \leq W_{2 \text { доn }}\right) \cup \ldots\right. \\
& \left.\ldots\left(W_{i} \leq W_{i \text { доn }}\right) \cup \ldots\left(W_{n} \leq W_{n \text { доn }}\right)\right\rfloor,
\end{aligned}
$$

де $W_{i}-$ розр хункове зн чення впливу $i$-го вр ж ючого ф ктор ;

$W_{i \text { до }}$ - допустиме зн чення впливу $i$-го вр ж ючого ф ктор н елемент

труктурн живучість

імовірність збереження мінім льно необхідної топологічної зв'яз ності їі елементів, тобто імовірність збереження сузірів в структурі

труктурн живучість визн ч ється [15]

$$
=\left(S_{i} \geq S_{\text {iдоn }}\right),
$$

де $S_{i}$ i $S_{i \text { доn }}-$ множин розр хункових $\mathrm{i}$ допустимих в сузір'ях, при яких ще можливе вирішення н віг ційної з д чі.

ід функціон льною живучістю PHC розуміють імовірність того, що кількість сузірїв
, які з лишилися після вогневого впливу противник $N_{\text {}}$, буде не меншою, ніж мінім льно необхідн кількість сузірїв $N_{\text {Ж потр.min }} 3$ допомогою якої ще можн з безпечити вирішення н віг ційної 3 д чі 3 необхідною якістю в 3 д ному р йоні. ункціон льн живучість визн ч ється вир зом

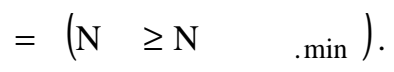

йдоцільнішим 3 точки зору живучості принципом побудови $€$ принцип структурної орг нізов ності. ей принцип поляг є у виборі р ціон льної орг ніз ційно-технічної, топологічної і функціон льної структур , які при цьому розгляд ються в орг ніз ційному, функціон льному, ч совому т технічному спект $\mathrm{x}$. ит нню оцінки живучості скл дних систем військового призн чення, якими $є$ i т

, присвячений ряд робіт $[13,14,16,17]$. ля оцінки їх живучості використовуються різні підходи н основі н ступних методів:

- імовірнісний;

- логіко-імовірнісний;

- евристичний;

- іміт ційного моделюв ння;

- моделюв ння опер цій

схемою 
роте 3 розвитком т інтегр цією 3 собів розвідки, i , існуючі методики оцінки живучості не дозволяють отрим ти повної оцінки всіх п р метрів функціонув ння , які безпосередньо вплив ють н живучість т вр зовують особливості топологічної, орг ніз ційно-технічної т функціон льної структур і дин міку функціонув ння ким чином, існуючі підходи до оцінки живучості скл дних систем військового призн чення, і зокрем , вр ховують ті чи інші пок зники їх функціонув ння, одн к 3 г лом нем є єдиного підходу, який би вр ховув в усі ці пок зники одноч сно, тобто пок зники, які х р ктеризують дин міку функціонув ння зі змінною структурою, що, в свою чергу, не н д $є$ змоги 3 дост тнім рівнем достовірності визн чити оптим льні п р метри упр вління просторово-ч совим випромінюв нням иходячи 3 вищезг д ного методик визн чення п р метрів оптим льного упр вління випромінюв нням м $є$ вр ховув ти дин міку функціонув ння , мобільність , що входять до її скл ду, розвідз хищеність т iï топологічну структуру. метою вирішення цього 3 вд ння пропонується н ступн методик визн чення п р метрів оптим льного упр вління випромінюв нням , як б зується н метод $\mathrm{x}$ моделюв ння опер цій 3 схемою м рковських вип дкових процесів, теорії імовірності т теорії гр фів, лгоритм якої н ведено н рис.2.

\section{Вихідні дані}

$\bar{t}_{\text {euxp. єunp, }}, \bar{t}_{\text {euxp, хееunp. }}$ - середній час вихриття випромінюючих та невипромінювапних сузір'ів РНТ розвідкою противнпка; $\bar{f}_{\text {же }}, \bar{t}_{\text {nidz }}-$ середній час видачі цілевказівок та середній час підготовки засобів ураження; $d$ - ступінь захищеності РНТ; a - тонність наведення та

2

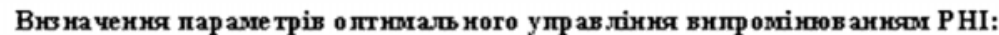

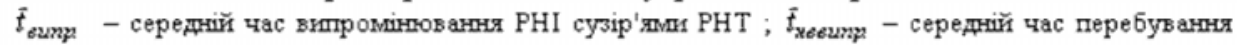
сузір'ів РНT в невипромінювальному стані; $U\left(i, t_{\text {eunрi }}\right)$ - агторитм постідовності зміни просторово-часової структури ПС РНС.

3

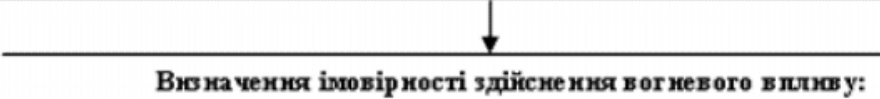
$P_{\text {ene }}(t)=P_{\text {pose }}(t) \cdot P_{\text {enei pose }}(t)$

4

Вюкачекия умовної імовірності ураженя ПС РНС ка об'ектовову рів ді

$$
P_{\text {ypax: } O}=\sum_{i=1}^{n} b_{i} P_{\text {ypaxcen }}
$$

5

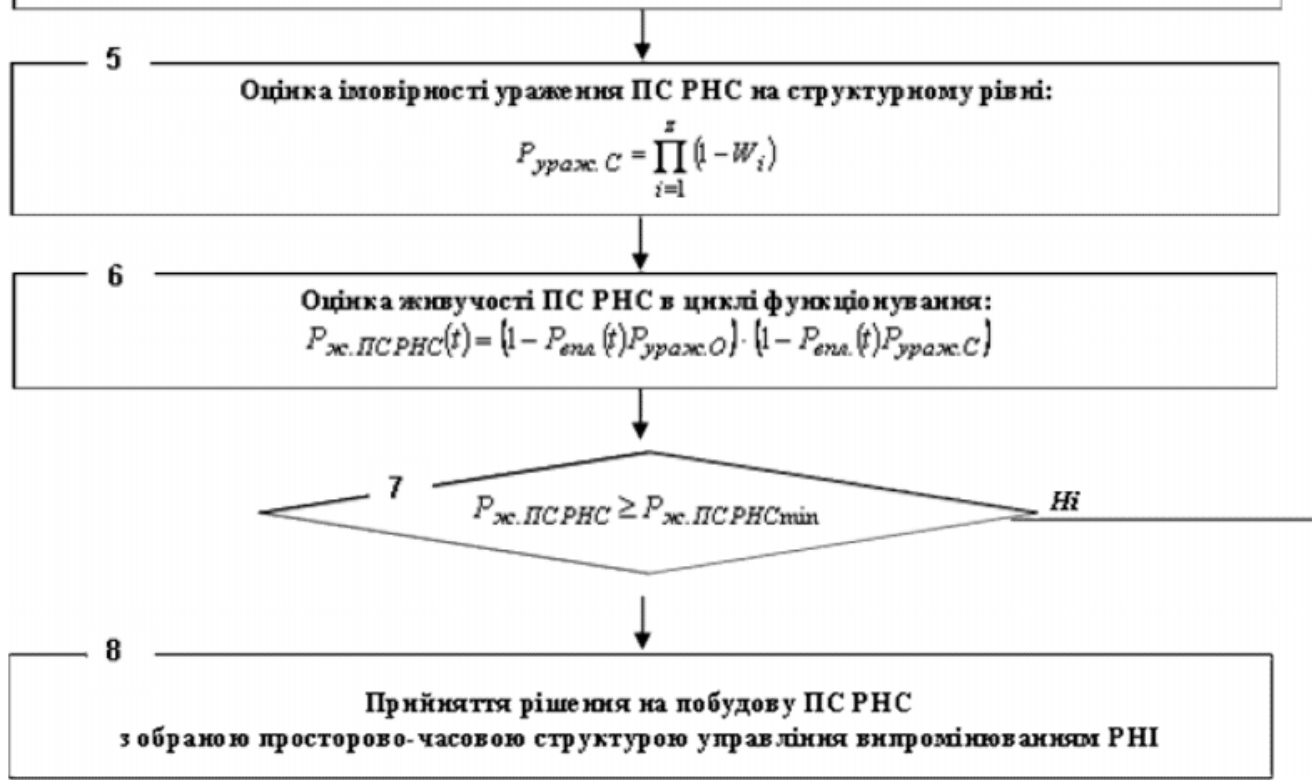

uc.2. лок-схем лгоритму визн чення просторово-ч сової структури упр вління випромінюв нням 
першому ет пі визн ч ються н ступні вихідні д ні:

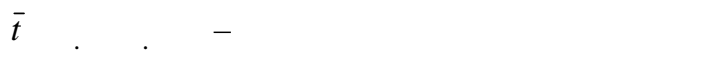

випромінюв льних сузірів розвідкою противник ; $\bar{t}_{\text {викр. невипр. }}-$ середній ч с викриття невипромінюв льних сузірїв розвідкою противник ; $\bar{t}_{\iota_{6}}-$ середній ч с вид чі цілевк зівок з соб м ур ження; $\bar{t}_{\text {niдг. }}$ - середній ч с підготовки з собів ур ження; $d$ - ступінь $з$ хищеності інженерної точки зору); $a$ - точність н ведення т потужність з діяного противником боєприп су згідно з його т ктико-технічними х р ктеристик ми $\mathrm{T}$ iн.

другому ет пі 3 вихідними д ними визн ч ються п р метри оптим льного упр вління випромінюв нням : $\bar{t}_{\text {випр. }}-$ середній ч с

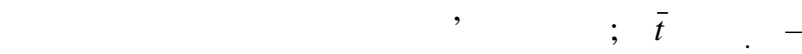
середній ч с перебув ння сузір’ів в невипромінюв льному ст ні; $U\left(i, t_{\text {випр. } i}\right)-$ лгоритм послідовності зміни просторово-ч сової структури

третьому ет пі н основі теорії гр фів визн ч ється імовірність здійснення вогневого впливу н елементи

четвертому ет пі визн ч ється умовн імовірність ур ження Н об'єктовому рівні 3 ур хув нням коефіцієнт в жливості $b_{i} i$-го елемент в структурі

п'ятому ет пі визн ч ється імовірність ур ження

шостому ет пі визн ч ється імовірність вижив ння в циклі їі функціонув ння.

н ступному кроці імовірність вижив ння в циклі їі функціонув ння порівнюється 3 обр ним пок зником.

ост нньому ет пі прийм ється рішення щодо оптим льності обр них п р метрів упр вління: якщо імовірність вижив ння у

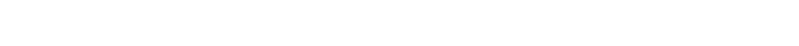
пок зник - н побудову з обр ною просторово-ч совою структурою упр вління випромінюв нням , якщо ні - н зміну п р метрів просторово-ч сового випромінюв ння .

\section{Иснов К И}

н ліз існуючих підходів до оцінки живучості пок з в, що вони не вр ховують одноч сно всіх орг ніз ційно-технічних пок зників, від яких 3 лежить живучість, зокрем просторово-ч сову дин міку функціонув ння

пропонов н методик дозволяє визн ч ти п р метри оптим льного упр вління випромінюв нням н основі оцінки живучості циклі іï функціонув ння. д ному вип дку створюється т к структур, в якій р діон віг ційні точки випромінюють р діон віг ційну інформ цію незн чний ч с, що необхідний, н прикл д, для вирішення прийм ч ми користув чів $1 \ldots 2$ циклів з д чі н віг ції. отім ці точки відключ ються, в роботу включ ються інші. е зменшує ч с випромінюв ння р діосигн лу, що, відповідно, зменшує вплив н зовнішніх ф кторів (н прикл д, под влення з соб ми чи фізичне знищення бо виведення 3 л ду з соб ми високоточної зброї противник ).

н веденій методиці одноч сно вр ховуються як опер тивні пок зники: середній ч с роботи обр них сузір їв н випромінюв ння перебув ння їх в невипромінюв льному ст ні, середній ч с викриття випромінюв льних т невипромінюв льних сузірїв , середній ч с вид чі цілевк зівок т підготовки з собів ур ження до 3 стосув ння, т к і технічні пок зники: в жливість елементів у структурі , х р ктер структурної пов'яз ності елементів, з стосув ння 3 ходів $з$ хисту від т ін. ри цьому живучість оцінюється н усіх ет п х в циклі іï функціонув ння.

од льшим н прямком досліджень доцільно визн чити розробку методики, як буде вр ховув ти дин мічність процесу ведення бойових дій т опер тивно змінюв ти п р метри упр вління в з лежності від умов обст новки, що скл л ся, т кож усув ти н слідки нешт тних ситу цій в процесі функціонув ння перерозподілу пр цезд тних між сузір'ями.

шляхом

\section{писок літер тури}

1. онцепція створення держ вної інтегров ної інформ ційної системи з безпечення упр вління рухомими об'єкт ми (зв'язок, н віг ція, спостереження). тв. розпорядженням бінету іністрів кр їни від 17 липня 2003 p. № $410-p$.

2. р вченко . . еория синтез псевдоспутниковых р дион виг ционных систем / . $р$ вченко. - .. , 2007. - 210 c.

3. ост нов бінету іністрів кр їни "ро з твердження ерж вної цільової н уково-технічної прогр ми створення держ вної інтегров ної інформ ційноӥ системи з безпечення упр вління рухомими об'єкт ми (зв'язок, н віг ція, спостереження)” від 17 вересня 2008 р. № 834.

4. стосув ння космічних систем для з безпечення дій збройних сил / [ стушенко . ., рисяжний . ., ндовський . . , 2001. $-108 c$

5. рг ніз ція б лістико-н віг ційного з безпечення упр вління космічними $п р т м и$ / [ івов . ., х ров . ., уменюк. . $m$ ін.]; $3 \quad 3$ г. ред. . івов . . . $\quad$, 2007. -508 c. 
6. ок льн р діон віг ційн систем : т. 68960 . кр їн. G01S5/02/. . осов, . . шков, . . $р$ вченко, . . вченко; - № 20031110538; з явл. 21.11.2003; опубл. 16.08.2004, юл.№ 8 .

7. етевые спутниковые р дион виг ционные системы / [ ебш евич . ., митриев . ., в ниевич . . и др.]; под ред. . . ебш евич.-[2-е изд.]. - . . дио и связь, 1993. - 408 с.

8. ценков . . сновы спутниковой н виг ции / . . ценков - .. оряч ялиния- елеком, 2005. - 272 c.

9. бк. . упутников р діон віг ція /

бк. ., онін . ., рченко . . - .. ехнік, 2004. $-328 c$.

10. лов рь по кибернетике / [под ред.

лушков . .]. - иев : $л$ вн я ред кция кр инской советской энциклопедии, 1979. - 358 c.

11. ябинин . . еоретические основы проектиров ния электроэнергетических систем кор блей/ . . ябинин- . : оенно-морск я к демия, 1964. -132 c.

12. лужний . . орівняльний нліз вл стивостей н дійності $m$ живучості скл дних систем військового призн чення / . . лужний, . . врінчук, . . єряков // истеми озброєння і військов технік . 2009. - № 4(20). - . 101-104.
13. дежнность и живучесть систем связи / [ удник . ., вч ренко . ., рлов . . и др.]; под ред. . . удник. - . : дио и связь, 1984. -216 с.

14. олик. . ффективность, н дежность $u$ живучесть сложных систем / . . олик, . . ябинин // втом тик и телемех ник . - 1984. - № 12. - . 151160.

15. врінчук. . етодик оцінки живучості псевдосупутникової р діон віг иійної системи зі змінною структурою / врінчук . ., лужний . ., р вченко . . // бірникн укових $п р$ иь ціон льного універсиету оборони кр їни "руди університету". 2010. - № 5 (98). - . .115-120.

16. еркесов . . етоды и модели оценки живучести сложных систем / . . еркесов- . : н ние, 1987. -285 c.

17. ябинин . . огико-вероятностные методы оценки н дежности структурно-сложных систем / . . ябинин, . . еркесов. - . . дио и связь, 1987. $216 c$.

дійщл доред кції 21.10.2010р.

ецензент: доктор технічних н ук, професор . . $\mathrm{p}$ вченко, ціон льний університет оборони кр їни, иїв.

вринчук

ст тье проведен н лиз существующих подходов к оценке жсивучести сложных систем военного н зн чения и предложен методик определения $n$ рлетров оптим льного упр вления излучением $p$ дион виг иионной информ ции, котор я б зируется н оценке живучести псевдоспутниковой р дион виг ционной системь в иикле ее функциониров ния.

лючевые слов : псевдоспутников я р дион виг ционн я систем, жсивучесть, $n$ р метры упр вления излучением р дион виг ционной информ ции.

\section{THE METHOD OF OPTIMAL CONTROL BY TIME-SPACE RADIATION OF RADIO-NAVIGATION INFORMATION PARAMETERS CALCULATING IN PSEUDO-SATELLITE RADIO-NAVIGATION SYSTEM}

O.V. Lavrinchuk

The article analyzes the existing approaches to evaluate the survivability of complex military systems and the method of optimal control by radiation of radionavigation information parameters calculating is proposed, which is based on the survivability evaluation of pseudo-satellite navigation system in a functioning cycle.

Keywords: pseudo-satellite navigation system, survivability, radiation control parameters of radionavigation information. 